\title{
当科における舌癌の臨床的検討
}

\author{
只 奎真122) - 羽嶋 正明1) $\cdot$ 久行 敦士 ${ }^{2)}$ \\ 立川 隆治2) ・平川勝洋2) ・夜陣 紘治 ${ }^{2)}$
}

\section{A Clinical Study of Tongue Carcinoma}

\author{
Keishin Go and Masaaki Hajima
}

(Hiroshima Prefectural Hospital)

\begin{abstract}
Atsushi Hisayuki, Takaharu Tatsukawa, Katsuhiro Hirakawa and Koji Yajin
(Hiroshima University)
\end{abstract}

\begin{abstract}
We report a clinical study of 60 patients with tongue carcinoma initially treated at Hiroshima University Hospital between 1993 and 2002. The overall 5 year survival rate was 81\% (Stage I; 93\%, Stage II; $84 \%$, Stage III; $90 \%$, Stage IV; 50\%). This paper shows that the control the cervical lymph node metastasis is an important factor for better prognosis and that external irradiation is an effective adjuvant therapy to control cervical lymph node metastasis.
\end{abstract}

Key words : tongue carcinoma, survival rate, treatment

はじめに

舌癌は頭頸部腫瘍の中でも比較的発生頻度が高く, そ の治療方法は各施設で種々の工夫がなされ，治療成績の 向上がみられるようになってきている.しかしながら外 見的に存在がわかりやすい部位であるわりに再発症例で は不幸な転㛿をとる例もみられる，今回，われわれは当 科に㧍いて過去 10 年間に初回治療を行った舌癌 60 例に ついて局所の制御率や頸部リンパ節転移の制御率などに ついて検討し，1978 年から 1992 年までの当科における 過去の舌癌の検討 ${ }^{1)}$ と比較したので報告する.

\section{対象および検討方法}

1993 年 1 月 1 日から 2002 年 12 月 31 日までの 10 年間 に治療を行った舌癌症例は 83 例であった.このうち再発 例や他院で治療した既往のある症例を除いた初回治療例 60 例に関して臨床的統計を行った。
1）性別および年別頻度

過去 10 年間の性別および年別頻度を図 1 に示した.

2）性別および年齢分布

60 例中男性 42 例, 女性 18 例と男性に多く性比はほぼ $2: 1$ であった. 初診時の年齢は $24 \sim 88$ 歳で図 2 のよう に 60,70 歳代に多く, 平均年齢は 61.4 歳であった.

3) 病理組織像

60 例中 59 例が扁平上皮癌（squamous cell carcinoma） であり，残りの 1 例が verrucous carcinoma であった.

4）TNM 分類および Stage 分類

60 例の TNM 分類および Stage 分類を表 1 に示す.

$\mathrm{T} 1: 14$ 例, T2 : 31 例, T3 $: 12$ 例, T4 $: 3$ 例であり, 過 去における当科の報告 ${ }^{1)}$ や諸家の報告 23 ) 2 と同様 $\mathrm{T} 2$ 症例 が最多であった。初診時頸部転移が認められた例は，19 例 $(31 \%)$ で，初診時遠隔転移のある症例は認めなかっ た. Stage 分類別では Stage I : 14 例, Stage II : 22 例,

1）県立広島病院耳鼻咽喉科頭頸部外科

2）広島大学耳鼻咽喉科学教室 


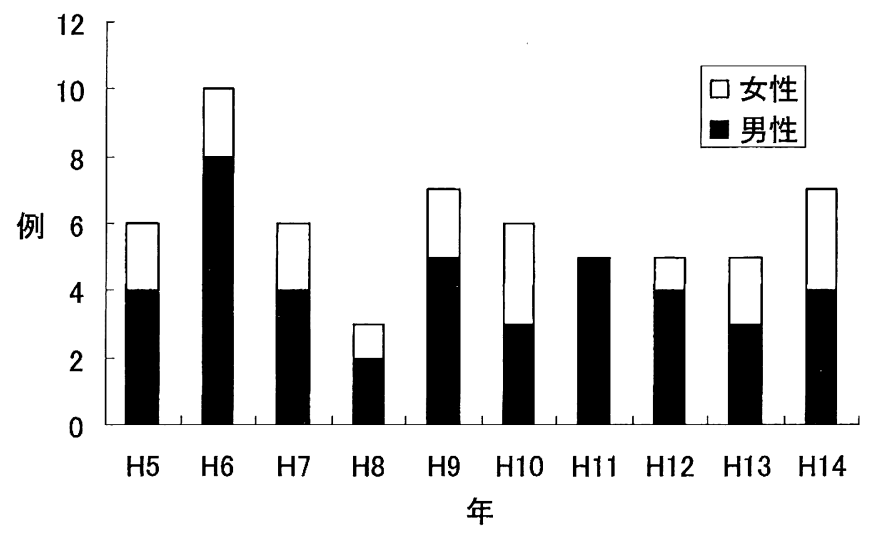

図 1 性別および年別頻度

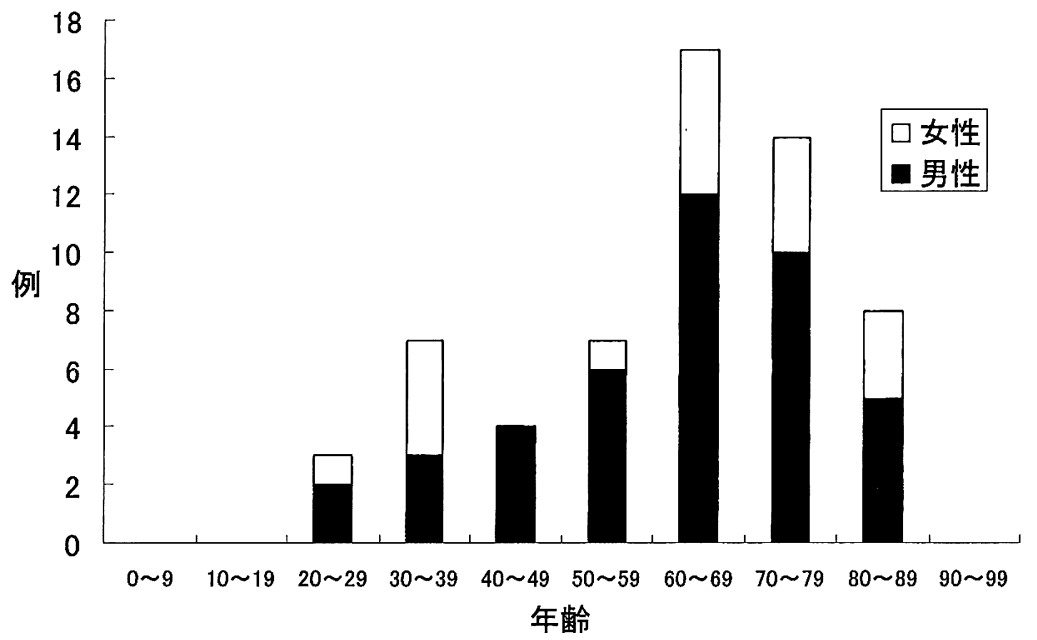

図 2 性別および年齢分布

表 1 TNM 分類と Stage 分類

\begin{tabular}{c|c|c|c|c|c}
\hline \hline & N0 & N1 & N2 & N3 & 計 \\
\hline T1 & 14 & 0 & 0 & 0 & $14(23 \%)$ \\
T2 & 22 & 5 & 4 & 0 & $31(52 \%)$ \\
T3 & 5 & 0 & 7 & 0 & $12(20 \%)$ \\
T4 & 0 & 0 & 3 & 0 & $3(5 \%)$ \\
\hline 計 & $41(69 \%)$ & $5(8 \%)$ & $14(23 \%)$ & 0 & 60
\end{tabular}

Stage I 14 例 $(23 \%) / 33 \%$

Stage II 22 例 $(37 \%) / 30 \%$

Stage III 10 例 $(17 \%) / 24 \%$

Stage IV 14 例 $(23 \%) / 13 \%$ / 後は過去の報告 
表 $2 \mathrm{~T}$ 分類別の局所再発率 $(\mathrm{T} 1+\mathrm{T} 2): 45$ 例

化学療法あり：22 例 再発率：5/22（23\%）

\begin{tabular}{|c|c|c|c|c|}
\hline 手術 放射線 & なし & Needling & 外 & Needling +外 \\
\hline なし & 0 & $3 / 11 \quad(27 \%)$ & $0 / 1 \quad(0 \%)$ & $1 / 7 \quad(14 \%)$ \\
\hline 部分切除 & 0 & $0 / 1 \quad(0 \%)$ & $1 / 2(50 \%)$ & 0 \\
\hline
\end{tabular}

化学療法なし：23 例 再発率 : 5/23（22\%）

\begin{tabular}{c|c|c|c|c}
\hline \hline 手術 & なし & Needling & 外 & Needling+外 \\
\hline なし & 0 & $1 / 9(11 \%)$ & $0 / 2(0 \%)$ & $1 / 4(25 \%)$ \\
\hline 部分切除 & $2 / 6(33 \%)$ & $1 / 2(50 \%)$ & 0 & 0 \\
& & 局所再発数/治療 (再発率) \\
Needling : 組織内照射 \\
外 : 外照射
\end{tabular}

表 $3 \mathrm{~T}$ 分類別の局所再発率 $(\mathrm{T} 3+\mathrm{T} 4) ： 15$ 例

化学療法あり：12 例 再発率：3/12（25\%）

\begin{tabular}{|c|c|c|c|c|}
\hline 手術放射線 & なし & Needling & 外 & Needling +外 \\
\hline なし & 0 & $1 / 2(50 \%)$ & $0 / 1 \quad(0 \%)$ & $2 / 4(50 \%)$ \\
\hline 半側切除 & $0 / 1 \quad(0 \%)$ & 0 & $0 / 2(0 \%)$ & 0 \\
\hline 全摘出 & 0 & 0 & $0 / 2(0 \%)$ & 0 \\
\hline
\end{tabular}

化学療法なし：3 例 再発率：1/3（33\%)

\begin{tabular}{c|c|c|c|c}
\hline \hline 手術 & なし & Needling & 外 & Needling +外 \\
\hline 半側切除 & 0 & 0 & $1 / 1(100 \%)$ & 0 \\
\hline 全摘出 & 0 & 0 & $0 / 2(0 \%)$ & 0 \\
& & & $\begin{array}{c}\text { 局所再発数/治療数 (再発率) } \\
\text { Needling : 組織内照射 } \\
\text { 外 : 外照射 }\end{array}$
\end{tabular}

Stage III :10 例, Stage IV:14 例で Stage I, II が 60\%を占め ていた。

5） $\mathrm{T}$ 分類別の局所治療法および局所再発率

$\mathrm{T}$ 分類別の局所治療法㧍よび局所再発率を表 2 , 表 3 亿 示した。 治療内容は化学療法, 放射線療法, 手術療法で ある，放射線療法としては組織内照射，外照射，外照射 十組織内照射が行われ, 手術療法としては部分切除, 半 側切除，全摘出が行われた。治療方法として組織内照射 の有無および手術療法の選択の境界が多くは $\mathrm{T} 2$ と $\mathrm{T} 3$ の 間であることより $\mathrm{T} 2$ 以下と $\mathrm{T} 3$ 以上に分けて, 検討を
行った. T1，T2 においては化学療法を併用している症 例（化学療法併用群）と，併用していない症例（化学療 法非併用群）はほぼ同数で，局所治療法は組織内照射が 中心となっている．T1，T2 においては化学療法併用の 有無によって局所再発率に差を認めない. T3，T4 にお いても同様に検討を行ったところ，ほとんどの症例にお いて化学療法を併用しており，さらに手術療法，放射線 療法を行っている. また, 化学療法非併用群においても, 手術療法，放射線療法の併用を行っている．T3，T4 で も化学療法併用の有無によって局所再発率に差を認めな 
い. 次に T3，T4 において手術療法の有無による局所再 発率について検討した。手術療法を併用した症例（手術 療法併用群）では局所再発率 $13 \%$ ，併用しなかった症例 （手術療法非併用群）では $42 \%$ と，手術療法併用群の方 が局所再発においては良好な成績であった。手術時再建 を行った症例は 12 例で, 再建材料としては, 胸三角皮弁 （以下 D-P flap）が 2 例，大胸筋皮弁（以下 PM-MC flap） が 4 例，D-P flap + PM-MC flap が 2 例，腹直筋皮弁が 2 例，前腕皮弁が 2 例に使用された。

6)初診時頸部転移が認められた症例の治療方法および 頸部再発

初診時頸部転移が認められた症例の頸部に対する治療 方法と頸部再発について表 4 亿示す。頸部転移のある症 例では集学的な治療が選択されており, 再発率について は，N1 では 40\%，N2 では 29\%であった。再発部位は, N1 では患側の頸部リンパ節にのみ再発を起こしている が，N2 では健側の顎下部に 2 例再発を認めている. その 他，前頸部，患側の頸部リンパ節に再発を認めている(図 3 , 図 4).

7）治療成績

i) Stage 分類別治療成績

Stage 分類別の生存曲線を図 5 に示す.全症例において は 81\%であった. Stage I では 93\%，Stage II では 84\%， Stage III では 90\%, Stage IV では 50\%であった. 当科にお ける過去の報告 ${ }^{1)}$ をカッコ内に示したが，過去の報告と 比較し，全 Stage にて治療成績の向上を認めた。

ii） $\mathrm{T}$ 分類別治療成績

T分類別の生存曲線を図6に示す. $\mathrm{T} 1$ では $93 \%, \mathrm{~T} 2$ では 81\%，T3 では 74\%，T4 では 50\%であった。当科におけ

表 4 初診時頸部転移が認められた症例の頸部に対する治療方 法と頸部再発率

\begin{tabular}{l|c|l|c}
\hline \hline 治療方法 & \multicolumn{1}{|c|}{$\mathrm{N} 1$} & \multicolumn{1}{|c|}{$\mathrm{N} 2$} & 計 \\
\hline $\mathrm{S}+\mathrm{R}+\mathrm{C}$ & 0 & $2 / 7(28 \%) *$ & 7 \\
$\mathrm{C}+\mathrm{R}$ & $0 / 2(0 \%)$ & $0 / 2(0 \%)$ & 4 \\
$\mathrm{~S}+\mathrm{R}$ & $1 / 1(100 \%)$ & $1 / 3(33 \%)$ & 2 \\
$\mathrm{~S}+\mathrm{C}$ & 0 & $1 / 1(100 \%) *$ & 1 \\
$\mathrm{~S}$ & 0 & $0 / 1(0 \%)$ & 1 \\
$\mathrm{C}$ & $1 / 2(50 \%)$ & 0 & 2 \\
\hline & $2 / 5(40 \%)$ & $4 / 14(29 \%)$ & 19 \\
& $\mathrm{~S}:$ 外科的療法 & 頸部再発数/治療数（再発率） \\
& $\mathrm{R}:$ 放射線療法 & *: 遠隔転移あり \\
& $\mathrm{C}:$ 化学療法
\end{tabular}

る過去の報告1）をカッコ内に示したが，これらの治療成 績も過去の報告より良好な結果であった。

8）初回治療後再発までの期間

初回治療後再発までの期間は 3 力月から 101 カ月で, そ の $50 \%$ は 5 月以内に，70\%は 8 カ月以内に再発をきた している.また, 1 年以上経過後の再発率は $13 \%$ であった.

9) 後発頸部リンパ節転移と局所再発の有無による 5 年 生存率

舌癌の予後を左右する因子として頸部リンパ節転移の 有無が主たるものといわれているが，その検討を行うた め初回治療後の後発頸部リンパ節転移および局所再発の 有無による 5 年生存率を比較した。

i）後発頸部リンパ節転移の有無による 5 年生存率

後発頸部リンパ節転移の有無による生存曲線を図 7 に 示す。転移が無い症例では $92 \%$ と良い成績だったのに対 し，有る症例では $65 \%$ と低い数字となっている.

ii）局所再発の有無による 5 年生存率

同様に局所再発の有無による 5 年生存率について検討

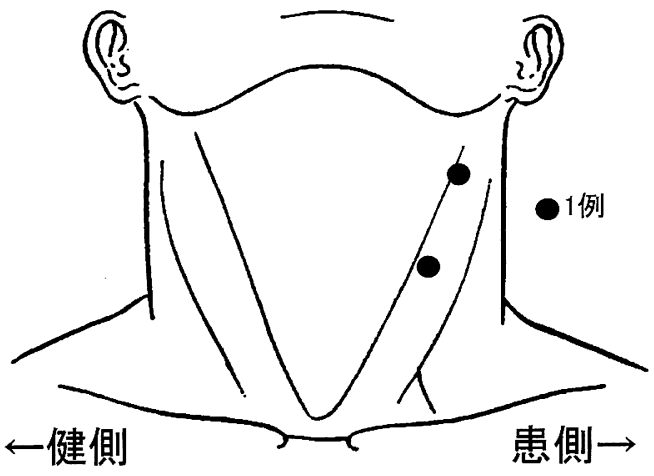

図 $3 \mathrm{~N} 1$ の再発部位

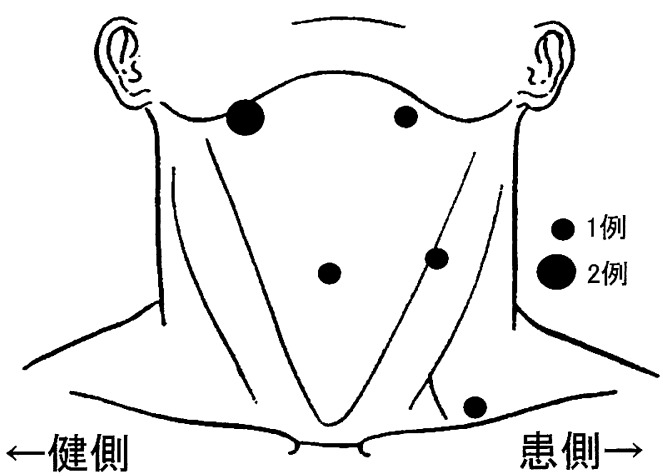

図 $4 \mathrm{~N} 2$ の再発部位 


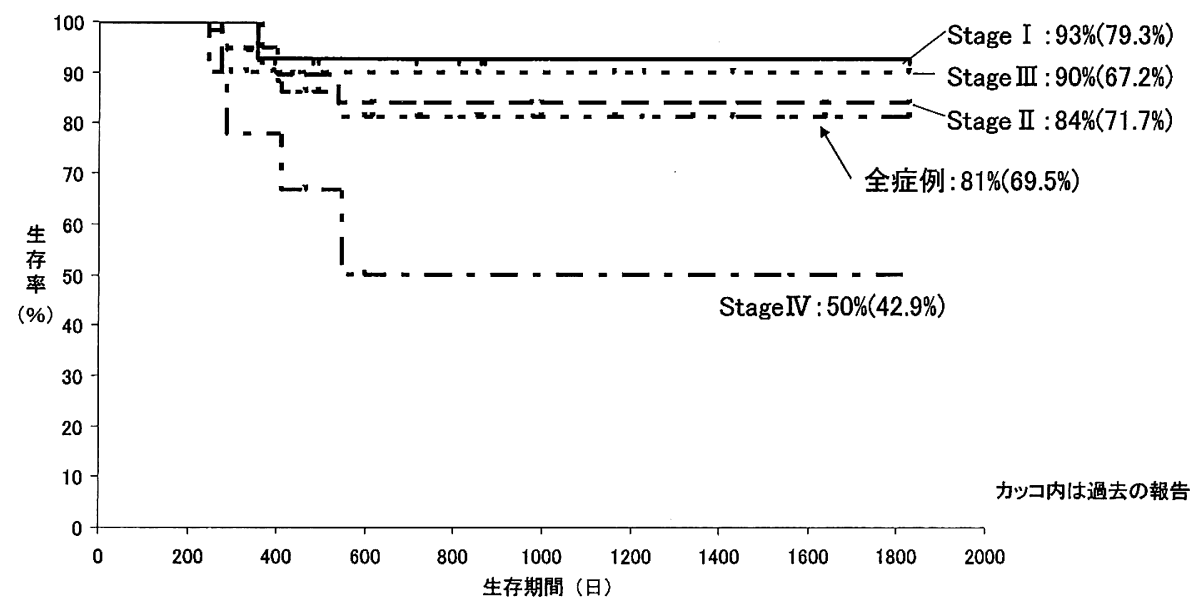

図 5 Stage 別 5 年生存率

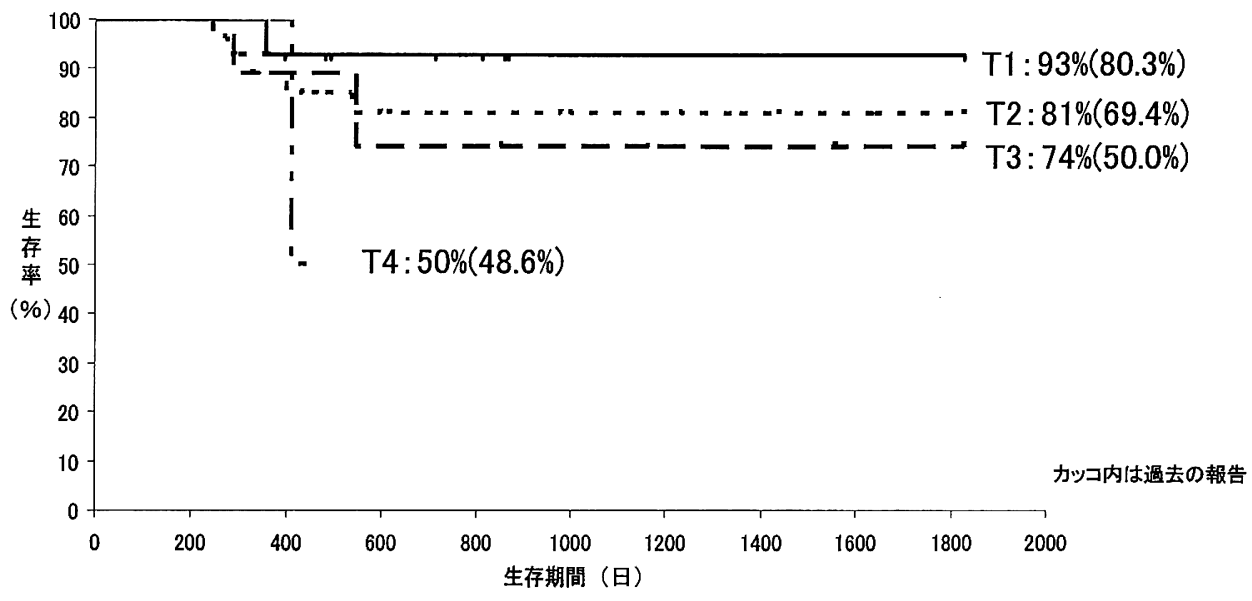

図 $6 \mathrm{~T}$ 分類別 5 年生存率

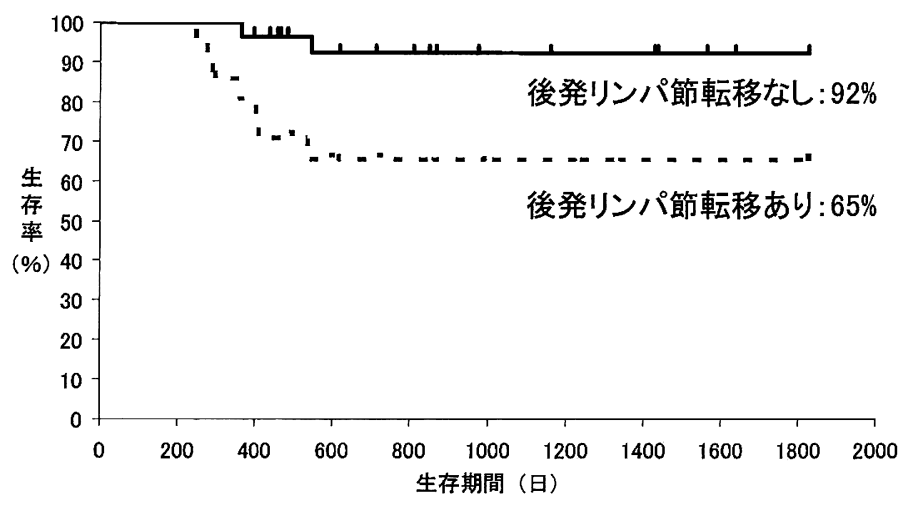

図 7 後発頸部リンパ節転移の有無による 5 年生存率 


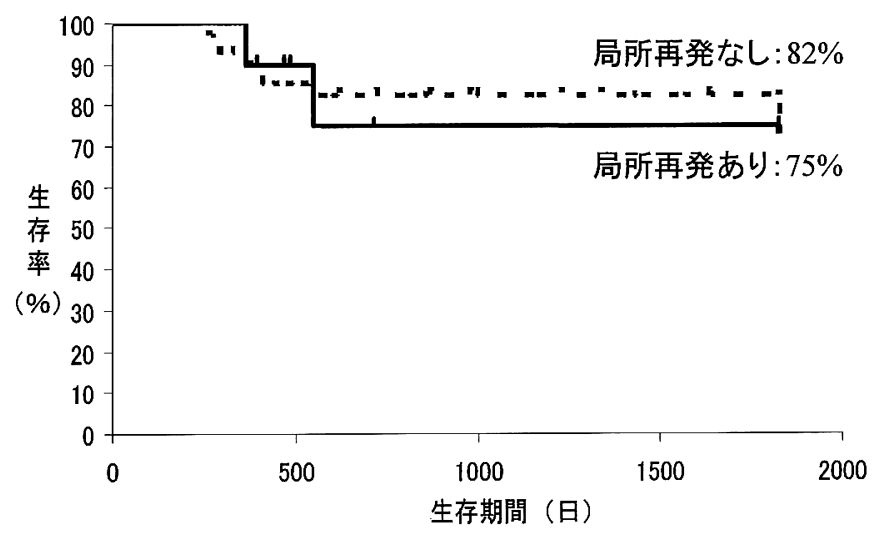

図 8 局所再発の有無による 5 年生存率

表 $5 \mathrm{~N} 0$ 症例 $(\mathrm{T} 1$ ～T3) の初回治療法と後発頸部リンパ節転移

\begin{tabular}{c|c|c}
\hline \hline & RT 併用群 & RT 非併用群 \\
\hline T1 & 0 & $6 / 14(43 \%)$ \\
T2 & $3 / 10(30 \%)$ & $7 / 12(58 \%)$ \\
T3 & $0 / 3(0 \%)$ & $1 / 2(50 \%)$ \\
\hline 全体 & $3 / 13(23 \%)$ & $14 / 28(50 \%)$ \\
& & 計 : $17 / 41(41 \%)$
\end{tabular}

した（図 8).

局所再発の無い症例では $82 \%$, 有る症例では $75 \%$ と大 きな差は認めなかった。

10) $\mathrm{T} 1 \sim \mathrm{T} 3 \mathrm{~N} 0$ 症例の初回治療法と後発頸部リンパ節 転移

以上のように舌癌の予後因子として頸部リンパ節転移 の有無が大切であるが，後発りンパ節転移を制御するた めには，どのよらな初回治療が有効かを検討するため， $\mathrm{T} 1 \sim \mathrm{T} 3 \mathrm{~N} 0$ 症例の初回治療法と後発頸部リンパ節転移と の関係を調べた（表 5).

全体でみると，放射線療法を併用している症例（放射 線療法併用群）では $23 \%$ に, 併用していない症例（放射 線療法非併用群）では $50 \%$ に後発頸部リンパ節転移が認 められた。 このように初回治療において放射線療法併用 群では後発頸部リンパ節転移が著明に少なくなっている ことがわかる、また，放射線療法併用群および非併用群 における後発頸部リンパ節転移部位を図 9 , 図 10 に示し た. 放射線療法併用群, 非併用群のどちらにも上頸部に おいて転移が多く認められている。

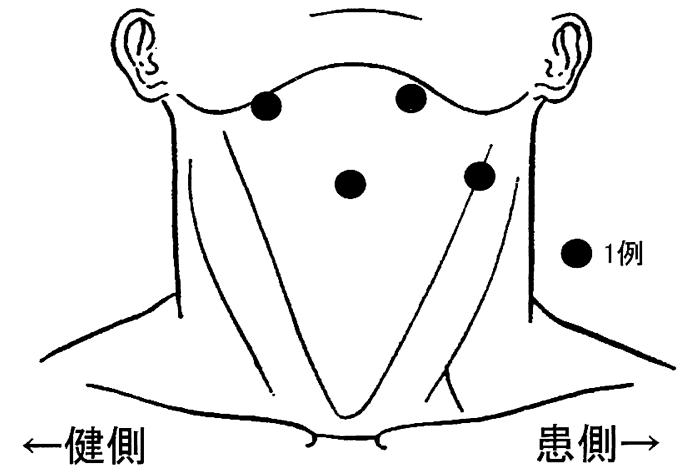

図 9 放射線療法併用群の後発頸部リンパ節転移

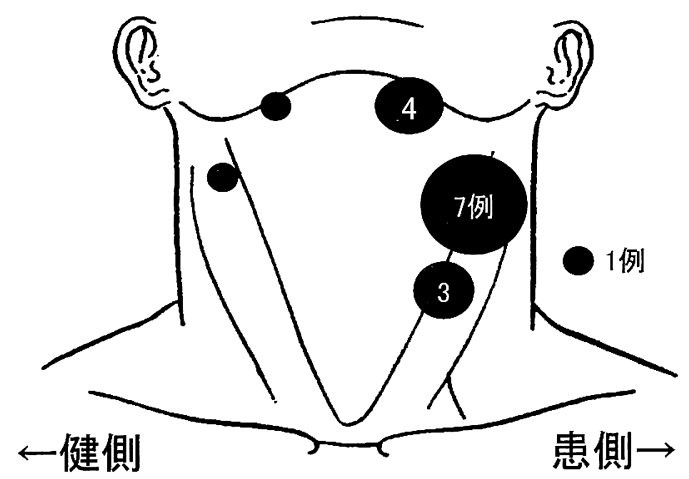

図 10 放射線療法非併用群の後発頸部リンパ節転移

考 察

舌癌の治療面に関しては治療成績の向上に努めること はもちろんであるが，構音，咀嚼，燕下に対して可能な 限り保存することが術後の quality of life の向上に重要で ある.このよらな観点から以前より当科では $\mathrm{T} 1, \mathrm{~T} 2$ に 
対しては，組織内照射を中心とした治療を行っている. その治療成績については過去のわれわれの報告1) や，他 施設での報告 ${ }^{4)}$ ７) でも成績は向上していることが裹付 けられており, 組織内照射の効果は大なるものがある. 今回の検討にても T1, T2 症例において手術療法群と組 織内照射群において治療効果に差はなかった。 今後も早 期舌癌に対しては組織内照射を中心に治療を進めるべき と考える.

舌癌進展例に関しては, 当科では以前より有茎弁や遊 離弁使用による再建術を加えた集学的治療を行っている が，T3，T4 症例で手術療法併用群での局所再発率は 42 $\%$, 手術療法非併用群での局所再発率は $13 \%$ と明らかに 手術療法併用群の局所制御率が良いことがわかった。 再 建材料として，遊離弁の使用も含めた再建を行っており 過去の報告1) に比べ治療成績が良好だった一つの要因と なっていると思われる.

化学療法を併用した治療を始めているが，局所制御率 および頸部リンパ節制御率ともに化学療法併用群と化学 療法非併用群とで有意な差は認められなかった。化学療 法の特徴として, 手術療法や放射線療法に対して悪影響 をおよぼさない，奏功の有無によりその後の治療を選択 できる（侵襲度を低くできる）といったことを考えると， 今後も化学療法併用にての治療を進めるべきであると考 える. また今後, 動注化学療法や booster chemotherapy を含めた化学療法も考慮すべき治療法である. 動注化学 療法は腫瘍局所に直接大量の抗癌剂を投与し，全身への 副作用を軽減できるという利点を持っているため, 抗腫 瘍効果が高く, 高齢者にも施行可能である. 脳血管障害 など動注化学療法の間題点もあるため, 治療基準につい てはこれからの検討課題ではあるが，積極的に取り入れ ていくべき治療と思われる ${ }^{8)}$. また一次治療終了後に CR にならなかった症例に対する booster chemotherapy は生 存率の向上に有用であるといら報告9）もあり，これも今 後積極的に取り入れていくべき治療と思われる.

舌癌の予後を左右する因子としては, 頸部リンパ節転 移の有無が主たるものといわれている1) 5110) が，今回の われわれの検討でも, 局所再発の有無により明らかな 5 年生存率の差は認めなかったのに対し, 後発頸部リンパ 節転移の有無により 5 年生存率に有意な差を認めた。す なわち，頸部リンパ節転移は予後を大きく左右する因子 であることを再認識させられた。

そこで N0 症例に対する治療で後発頸部リンパ節転移
の有無を調べたところ，全体で $41 \%$ に転移が認められた のに対し，放射線療法併用群では $23 \%$, 放射線療法非併 用群では $50 \%$ に転移が認められた。舌癌 $\mathrm{N} 0$ 症例におい て，後発頸部リンパ節転移を防ぐのに，放射線外照射の 有効性が示唆された，放射線療法併用群では，ほとんど の症例において，上頸部に $30 \mathrm{~Gy}$ の放射線外照射をかけ た後，組織内照射を行うという方法であった，照射範囲 としては，患側の局所の舌・オトガイ部・顎下部・上内 深頸リンパ節まで含まれている．照射後の後発頸部リン パ節転移部位を検討してみると，ほとんどの症例におい て照射野に再発を認めていることより，照射野を拡大し たからといって再発を防ぐことができるわけではないと 思われる．しかし，照射線量の増加，他の治療（化学療 法など）を組み合わせるといった工夫については今後検 討すべき課題であろう。

\section{まとめ}

1） 1993 年から 2002 年の 10 年間に当科において初回 治療を行った舌癌 60 例について統計学的検討を行った。

2) Stage 別 5 年生存率では, Stage I では $93 \%$, Stage II では 84\%, Stage III では 90\%, Stage IV では 50\%であっ た.

3）全体の 5 年生存率は $81 \%$ であった。

4）舌癌の最大の予後因子は後発頸部リンパ節転移の 有無であり, N0 症例において後発頸部リンパ節転移を抑 えるのに放射線療法が有用であった。

\section{参考文献}

1）田村千春, 川本浩子, 益田 慎, 他：当科沶ける舌癌の 臨床的検討. 耳鼻臨床 補 $72: 31 \sim 36,1994$.

2）寺山善博，米本正明，長舩宏隆，他：舌癌の臨床的検討. 耳喉頭頸 $73: 37 \sim 41,2001$.

3）寺尾恭一, 森 一功, 楠 威志, 他 : 舌癌 124 症例の踟床 的検討. 耳鼻臨床 $96: 317 \sim 322,2003$.

4）三谷浩樹，鎌田信悦，苦瓜知彦，他：stage I - II 舌癌の治 療成績について. 耳展 $45: 35 \sim 43,2002$.

5）益田宗幸，國武直信，中島寅彦，他：舌癌 T2NOM0 症例(3) 九州大学の場合. 耳堠頭頸 $70: 483 \sim 486,1998$.

6）赤植詩朗, 猪原秀典, 山本佳史, 他 : 早期舌癌症例の治療 成績. 耳鼻臨床 $96: 553 \sim 557,2003$.

7）湯田厚司，岸岡陸子，立松正規，他：口腔癌の臨床統計。 耳鼻臨床 $95: 933 \sim 937,2002$.

8）横山純吉：頭頸部癌. 癌と化学療法 $29 ： 169 \sim 175,2002$.

9）鈴木健二，伊藤靖浩，奥村耕司，他：舌癌住対する化学療 
法一術前・術後化学療法一. 耳鼻 $47: 6 \sim 10,2001$.

10）三谷浩樹, 鎌田信悦, 苦瓜知彦, 他 : stage III · IV 舌癌の 治療成績について. 耳展 $46: 134 \sim 143,2003$.
別刷請求先 : 只 奎真

勇734-8530 広島市南区宇品神田1-5-54

県立広島病院耳鼻咽喉科・頭頸部外科 